\title{
Studies of propane flame soot acting as heterogeneous ice nuclei in conjunction with single particle soot photometer measurements
}

\author{
I. Crawford ${ }^{1}$, O. Möhler ${ }^{2}$, M. Schnaiter ${ }^{2}$, H. Saathoff ${ }^{2}$, D. Liu ${ }^{1}$, G. McMeeking ${ }^{1}$, C. Linke ${ }^{2}$, M. Flynn ${ }^{1}$, K. N. Bower ${ }^{1}$, \\ P. J. Connolly ${ }^{1}$, M. W. Gallagher ${ }^{1}$, and H. Coe ${ }^{1}$ \\ ${ }^{1}$ Centre for Atmospheric Science, School of Earth, Atmospheric and Environmental Sciences, University of Manchester, \\ M13 9PL, Manchester, UK \\ ${ }^{2}$ Institute for Meteorology and Climate Research, Karlsruhe Institute of Technology, Postfach 3640, 76021 Karlsruhe, \\ Germany
}

Received: 1 March 2011 - Published in Atmos. Chem. Phys. Discuss.: 8 April 2011

Revised: 8 September 2011 - Accepted: 10 September 2011 - Published: 16 September 2011

\begin{abstract}
The ice nucleation efficiency of propane flame soot particles with and without a sulphuric acid coating was investigated using the aerosol and cloud chamber facility AIDA (Aerosol Interaction and Dynamics in the Atmosphere). The test soot for cloud formation simulations was produced using a propane flame Combustion Aerosol Standard generator (CAST, Jing-CAST Technologies). The organic carbon content (OC) of the test soot was altered in a reproducible fashion by changing the fuel/air mixture of the generator. The soot content of ice nuclei was subsequently investigated using a combination of a pumped counterflow virtual impactor (PCVI) to separate and evaporate the ice crystals, and a DMT single particle soot photometer (SP2) to examine the mixing state of the $\mathrm{BC}$ containing ice residuals.

Ice nucleation was found to be most efficient for uncoated soot of low organic carbon content ( $\sim 5 \%$ organic carbon content) where deposition freezing occurred at an ice saturation ratio $S_{\text {ice }} \sim 1.22$ at a temperature $T=226.6 \mathrm{~K}$ with $25 \%$ of the test soot becoming active as ice nuclei. Propane flame soot of higher organic carbon content $(\sim 30 \%$ and $\sim 70 \%$ organic carbon content) showed significantly lower ice nucleation efficiency (an activated fraction of the order of a few percent in the experiments) than the low organic carbon content soot, with water saturation being required for freezing to occur. Ice nucleation occurred over the range $S_{\text {ice }}=1.22-1.70$, and $T=223.2-226.6 \mathrm{~K}$. Analysis of the SP2 data showed that the $5 \%$ organic carbon content soot had an undetectable OC coating whereas the $30 \%$ organic carbon content soot had a thicker or less volatile OC coating.
\end{abstract}

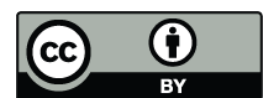

Correspondence to: I. Crawford (i.crawford@manchester.ac.uk)
The application of a sulphuric acid coating to the flame soot shifted the threshold of the onset of freezing towards that of the homogeneous freezing of sulphuric acid; for the minimum OC flame soot this inhibited nucleation since the onset of freezing occurred at colder temperatures and required a greater ice saturation ratio; for the medium and maximum OC flame soot, the addition of a sulphuric acid significantly reduced the freezing threshold.

\section{Introduction}

Many studies of cirrus and orographic cloud formation have focussed on the homogeneous freezing of supercooled sulphuric acid droplets as the major mechanism (Archuleta et al., 2005; Field et al., 2001; Haag et al., 2003; Heymsfield and Miloshevich, 1993; Heymsfield and Sabin, 1989; Jensen et al., 1998; Marti and Mauersberger, 1993; Sassen and Dodd, 1988; Tabazadeh et al., 1997). Numerical parameterisations have been developed to estimate the ice crystal number concentration and size for given conditions, and solutes, which can then be used to determine cloud radiative properties (Kärcher, 2002; Kärcher and Lohmann, 2003; Koop et al., 2000; Lohmann and Kärcher, 2002). However, many field studies have shown cirrus formation via heterogeneous freezing at conditions below the homogeneous freezing threshold (DeMott et al., 1998; Heymsfield et al., 1998; Rogers et al., 1998; Seifert et al., 2003).

In heterogeneously induced cirrus the maximum supersaturation is limited to values below the homogeneous freezing threshold as the ice crystals grow by the uptake of water vapour. This results in optically thin layers of cloud comprised of a low number of large crystals which are

Published by Copernicus Publications on behalf of the European Geosciences Union. 
radiatively different to their homogeneously induced counterparts (Gierens, 2003; Kärcher and Lohmann, 2003).

Given its ubiquity in the atmosphere, if soot behaves as an efficient ice nucleus (IN) then it may have potential to impact climate by modifying the lifecycle and optical properties of mixed phase and glaciated clouds (DeMott et al., 1997; Gierens, 2003; Lohmann, 2002; Lohmann and Feichter, 2005) particularly in sensitive regions of the globe such as the Arctic and Antarctic. Soot may offer significant concentrations of active IN in the lower troposphere where an increase in ice crystal number concentration may result in more rapid and frequent glaciation of mixed phase clouds by the Bergeron-Findeisen process (Lohmann and Feichter, 2005; Rogers and Yau, 1996; Schwarzenbock et al., 2001). This would likely act to reduce cloud top albedo and increase ice phase precipitation, reducing cloud lifetime. However these effects are highly uncertain and estimates of the forcings associated with IN are largely unknown (Lohmann, 2002; Lohmann and Feichter, 2005; Penner et al., 2001). The effects of soot will be of great significance if the type of soot emitted can act as an efficient ice nucleus or if once in the atmosphere it is processed in such a way as to promote ice activation. Studies by DeMott et al. (1999) and Kärcher and Lohmann (2003) suggest that the activation of ice upon soot may explain the formation of visible contrails behind aircraft. Modelling studies by Jensen and Toon (1997) showed that cirrus formed by homogeneous freezing is markedly different in behaviour to that formed by heterogeneous freezing mechanisms: homogeneously nucleated cirrus was shown to be transient in nature, precipitating quickly whereas cirrus formed by the heterogeneous freezing on soot was found to be much more persistent and diffuse. More recently studies by Kärcher et al. (2007) concluded that the effect of aircraft soot on cirrus formation is highly complex and was dependent on many emission and environmental parameters; the use of a microphysical-chemical model found that high concentrations of soot may increase the number of ice crystals and conversely low concentrations of soot coagulated with background aerosol could significantly reduce ice crystal number. It was noted that the source and ageing processes were crucial factors in determining the ice nucleation efficiency of soot, stating that coated soot particles are poor ice nuclei when compared to their bare counterparts (Kärcher et al., 2007).

There have been relatively few laboratory studies examining soot's behaviour as a potential IN partly due to the difficulty in designing an experiment to probe the soot particles subsequently contained within cloud ice crystals and also because of the problems inherent in sourcing suitable and reproducible test soot. Investigations have used different experimental techniques and different soot production and characterisation methods which also makes direct comparison of reported results difficult, however they all suggest that soot may be a significant source of atmospheric IN as noted by Dymarska et al. (2006) (DeMott, 1990; Diehl and Mitra,
1998; Dymarska et al., 2006; Gorbunov et al., 2001; Kärcher et al., 2007; Koehler et al., 2009; Möhler et al., 2005a,b). The development of the single particle soot photometer (SP2) has added to our ability to measure soot size and concentrations with high sensitivity, and is ideally suited for this type of analysis. Analysis of the SP2 data has allowed us to examine the mixing state and coating physical properties of the produced test soot and to compare soots of different organic carbon content. Since the SP2 measures both elastic scatter and incandescence it is possible to determine whether the sample aerosol contains incandescent material, allowing the fraction of the aerosol population containing refractory black carbon to be estimated.

\section{Experimental method}

\subsection{Cloud chamber and soot generation}

Cloud simulation experiments were performed in the large Aerosol Interactions and Dynamics in the Atmosphere (AIDA) chamber facility (Benz et al., 2005; Möhler et al., 2008, 2005a, 2006). The $84 \mathrm{~m}^{3}$ aerosol vessel (Fig. 1) is enclosed within a large insulating box that can be chilled to a temperature of $238 \mathrm{~K}$ using conventional compressors. Evaporating liquid nitrogen in the heat exchangers can further cool the chamber to a temperature of $183 \mathrm{~K}$. The aerosol vessel is initially evacuated to a pressure below $0.1 \mathrm{hPa}$ and then refilled with particle free synthetic air to minimise the background aerosol concentration $\left(N_{\mathrm{p}}<0.1 \mathrm{~cm}^{-3}\right)$. The chamber walls are coated with a thin layer of ice which maintains a high relative humidity of 90-95\% with respect to ice within the vessel under constant temperature and pressure conditions. Supersaturation with respect to ice can be achieved through expansion cooling by reducing the vessel pressure with two large pumps through a $10 \mathrm{~cm}$ diameter pipe connected to the top of the chamber. The cooling rate can be varied between 0.1 to $4 \mathrm{~K} \mathrm{~min}^{-1}$, assuming a dry adiabatic lapse rate of $9.75 \mathrm{~K} \mathrm{~km}^{-1}$ this equates to updraft velocities of $0.15 \mathrm{~m} \mathrm{~s}^{-1}$ to $6.5 \mathrm{~m} \mathrm{~s}^{-1}$ in the troposphere, respectively (Möhler et al., 2003). Further details of the AIDA facility and its instrumentation can be found in (Möhler et al., 2008, 2005a,b, 2003; Wagner et al., 2009).

Combustion soot aerosol was generated using a JingCAST Technologies Combustion Aerosol Standard (CAST) propane burner. Note in this paper we use the term "soot" to refer to all particles produced by the CAST generator and "rBC" for material detected by the SP2 via laser-induced incandescence. The CAST generates the test aerosol within a co-flow diffusion of propane flame and particle free sheath air in a total flow of $291 \mathrm{~min}^{-1}$ at $1013 \mathrm{hPa}$ and $273 \mathrm{~K}$. By varying the propane-air ratio, a range of soot containing of the order of a few percent organic carbon content to organic carbon contents of up to $80 \%$ can be generated in a repeatable fashion (Schnaiter et al., 2006). 


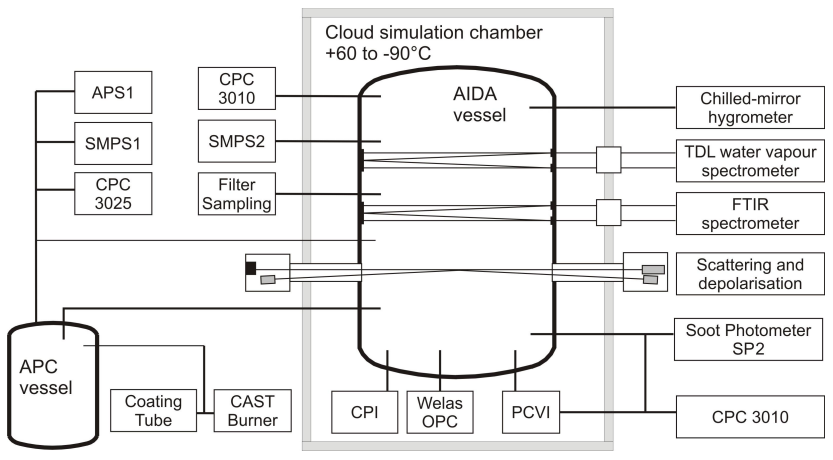

Fig. 1. Schematic of the AIDA cloud simulation chamber with instrumentation for heterogeneous ice nucleation studies of soot aerosols.

The organic carbon content of the soot was determined using an off-line thermographic technique. Combustion aerosol samples were deposited onto quartz fibre filters which were then analysed over three temperature stages; in the first stage low volatility $\mathrm{OC}$ compounds were volatilised in $350^{\circ} \mathrm{C}$ helium flow and then catalytically oxidised. The carbon fraction was determined as $\mathrm{CO}_{2}$ by NDIR spectrometry; in the second stage, the remaining less volatile OC compounds were volatilised in a $650^{\circ} \mathrm{C}$ helium flow; in the final stage the remainder of the sample was burned in a $650^{\circ} \mathrm{C}$ oxygen flow and the detected carbon fraction was classified as Elemental Carbon (EC), allowing the EC/OC ratio to be calculated. Organic carbon amounts given in this paper always refer to the sum of both the volatile and less volatile fractions analysed thermographically. Further details can be found in Schnaiter et al. (2006).

A mini-CAST (Jing-CAST Technologies) propane burner was used for a subset of experiments which exhibit a slight change in the composition of the same soot for the same gas flows. Figure 3 shows the OC/EC ratios for a given $\mathrm{C} / \mathrm{O}$ burning ratio as detailed in Schnaiter et al. (2006).

A comparison of the aerosol size distributions for each of the soots generated with the CAST and mini-CAST generator is given in Fig. 4. Note that the coagulation times of the soot in the NAUA chamber before injection into the AIDA chamber were longer for the IN09 case, which explains the difference in modal diameters.

Soot aerosol generated by the CAST produces the majority of the number concentration in the sub- $0.1 \mu \mathrm{m}$ diameter range. This soot is injected into a smaller chamber (NAUA, $3.7 \mathrm{~m}^{3}$ in volume) at ambient temperatures where it is left to coagulate to form a number distribution with a modal mobility diameter of approximately $0.3 \mu \mathrm{m}$ as measured with a Scanning Mobility Particle Sizer before being injected into the AIDA chamber (Fig. 2). Transmission Electron Microscopy analysis showed the soot aggregates generated with the CAST to typically consist of small individual particles of aproximately $0.03 \mu \mathrm{m}$ in diameter with larger spherical

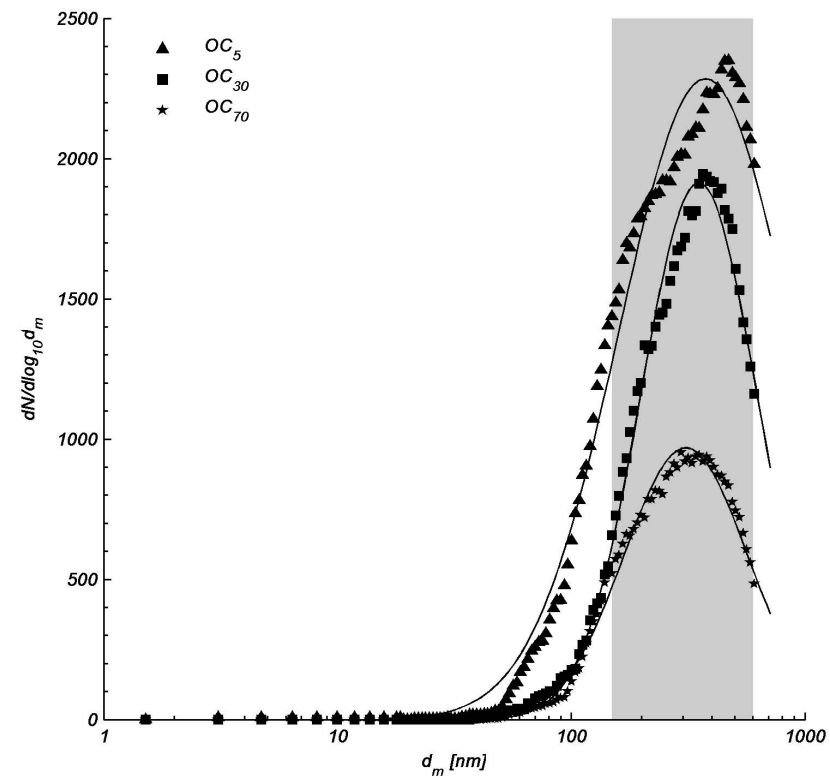

Fig. 2. Size distributions of CAST soot as measured with an SMPS; $5 \%$ (triangle), $30 \%$ (square) and $70 \%$ (star) organic carbon (OC) content after growth in the NAUA aerosol chamber prior to injection into the AIDA aerosol chamber. Area enclosed in grey shows the detection range of the SP2.

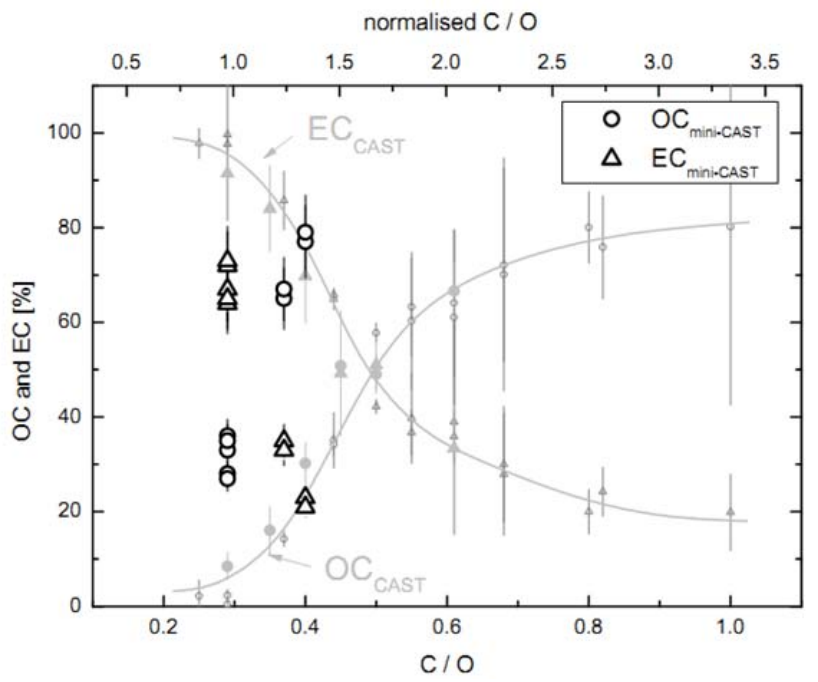

Fig. 3. Dependence of the particle composition (OC and EC content) on the $\mathrm{C} / \mathrm{O}$ atomic ratio in the burner. Full symbols indicate measurements on samples from the NAUA chamber, open symbols indicate samples taken directly behind the CAST burner. For further details see Schnaiter et al. (2006).

particles of up to $0.12 \mu \mathrm{m}$ in diameter also being present (Schnaiter et al., 2006). Comparison of this soot to previous studies is difficult as in many of the studies the aerosol population was poorly defined. The Möhler et al. (2005a) study using a comercial graphite spark generator found the primary 


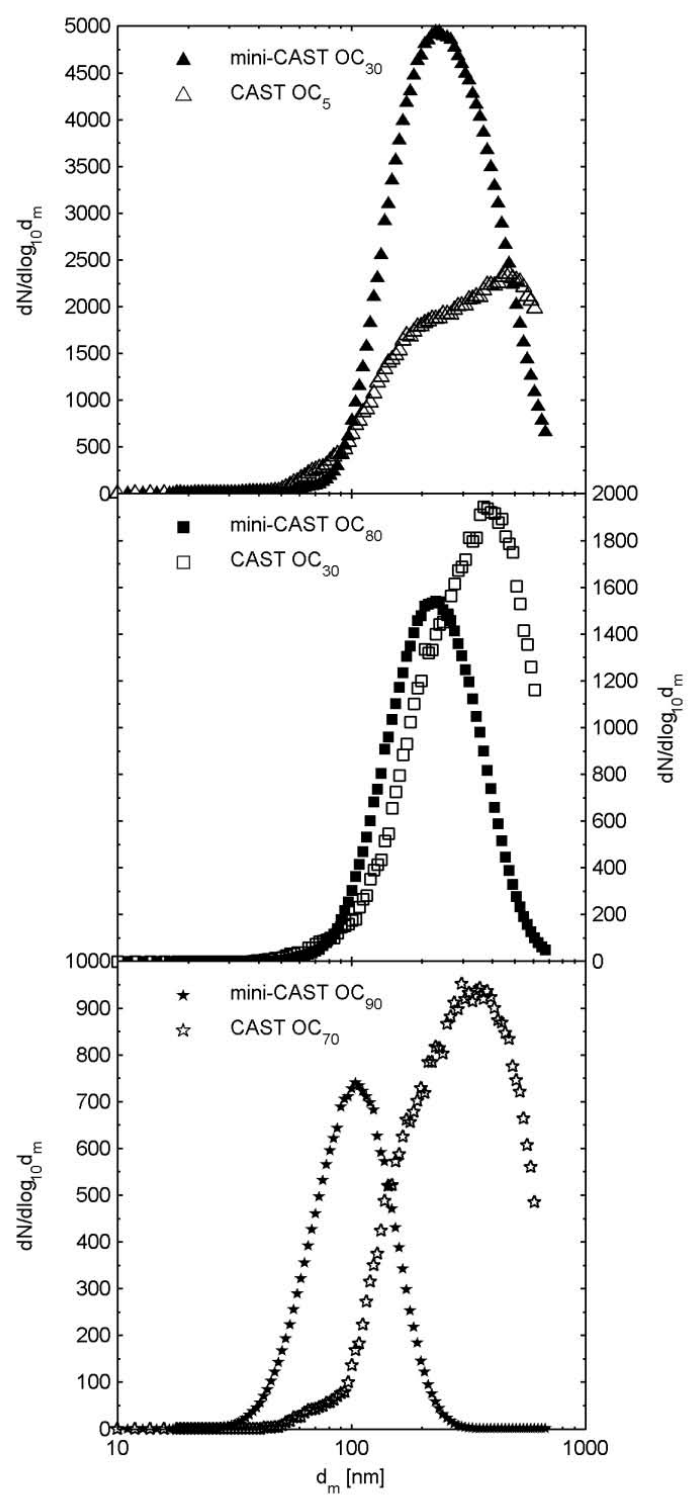

Fig. 4. Comparison of size distributions of mini-CAST and CAST soot as measured with an SMPS; $30 \% / 5 \%$ (top), $80 \% / 30 \%$ (middle) and $90 \% / 70 \%$ (bottom) organic carbon (OC) content after growth in the NAUA aerosol chamber prior to injection into the AIDA aerosol chamber. Note: the coagulation times of the soot in the NAUA chamber before injection into the AIDA chamber were longer for the IN09 case, which explains the difference in modal diameters.

particles to be between 4 to $8 \mathrm{~nm}$ in diameter and these were aggregated to around $0.09 \mu \mathrm{m}$ in a small chamber. Diehl and Mitra (1998) used a kerosene burner in their study to produce aggregates of 0.10 to $0.12 \mu \mathrm{m}$ in diameter. No estimate of the primary particle size were made but it was noted by the authors that $80 \%$ of the particles produced were smaller than $0.09 \mu \mathrm{m}$ in diameter. DeMott et al. (1999) used comercial Degussa lamp black carbon which quotes an average size of $0.095 \mu \mathrm{m}$ with aggregates being lognormally distributed with a mean diameter of $0.24 \mu \mathrm{m}$. Dymarska et al. (2006) studied a multitude of different soot types using a flow cell arrangement but only note that the majority of particles were between 1 and $20 \mu \mathrm{m}$ in diameter. Saathoff et al. (2003) investigated soot generated using a Diesel engine which yielded primary particles smaller than $0.05 \mu \mathrm{m}$ in diameter which were aggregated (along with ammonium sulphate) to modal sizes of approximately $0.25 \mu \mathrm{m}$.

For the soot characterisation experiments, three distinctly different soots were generated: (a) minimum organic carbon content soot ( $\sim 5 \%$ organic carbon content by mass), (b) medium organic carbon content soot $(\sim 30 \%$ organic carbon content) and (c) maximum organic carbon content soot ( $\sim 60 / 70 \%$ organic carbon content). Hereafter these classifications for minimum, medium and maximum organic carbon content particles will be referred to as $\mathrm{OC}_{5}, \mathrm{OC}_{30}$ and $\mathrm{OC}_{70}$ respectively.

During a subset of experiments the mini-CAST propane burner was used and the propane flame soot particles were coated with sulphuric acid by mixing the soot aerosol with a flow of synthetic air saturated with sulphuric acid vapour in a temperature controlled flow tube. Sulphuric acid vapour was condensed onto the soot upon cooling of the saturated mixture in a temperature gradient flow tube; the temperature in the saturator was set to $55^{\circ} \mathrm{C}$ and $45^{\circ} \mathrm{C}$ for the $\mathrm{OC}_{5}$ and $\mathrm{OC}_{70}$ experiments respectively, the temperature of the mixing region at the beginning of the coating tube was set $20^{\circ} \mathrm{C}$ higher than the saturation region. Within the $1.5 \mathrm{~m}$ long flow tube ( $16 \mathrm{~mm}$ internal diameter) the temperature decreased to about $30^{\circ} \mathrm{C}$. The total flow rate through the coating tube was between 30 to 34 Standard Litres per Minute. The nucleation of pure sulphuric acid droplets was suppressed by adjusting the flow rates and cooling gradient profile.

\subsection{Cloud, aerosol and black carbon measurements}

Aerosol measurements were made by directly sampling from the AIDA chamber both prior to and during cloud simulation experiments. During cloud simulation experiments it was possible to measure cloud particle residual aerosol using a Pumped Counterflow Virtual Impactor (PCVI), similar in design to that described by Boulter et al. (2006). This instrument produces a barrier flow to incoming sampled particles allowing only those greater than a certain size (i.e. with a characteristic momentum) to penetrate and be sampled. The recirculating particle-free dry barrier flow also evaporates the ice to leave the residual assumed IN, particle. Characterisation of the PCVI showed that the $50 \%$ transmission size $\left(D_{50}\right)$ was approximately $5 \mu \mathrm{m}$. Aerosol residuals were analysed using a number of instruments but for this work we focus on measurements of $\mathrm{rBC}$ core mass and associated coatings made by a Single Particle Soot Photometer (SP2; DMT, Boulder, Colorado, USA) (Baumgardner et al., 2004; Schwarz et al., 2006; Stephens et al., 2003). The SP2 was available for the first series of experiments examining 
soot (rBC plus any associated organics), but not the second series of experiments when soot particles were also coated with sulphuric acid. Aerosol is drawn into the SP2 where the air jet containing the sample intersects a Nd:YAG, intracavity, continuous laser beam $(\lambda=1064 \mathrm{~nm})$. Laser light scattered by sample particles of detectable size is detected by an avalanche photodetector (ADP) and related to particle size by means of calibration with polystyrene latex spheres (PSL).

Refractory and strongly light-absorbing aerosol particles (including black carbon) of sufficient size will absorb energy and become heated to their boiling or vaporization temperature when they will start to incandesce. Emitted thermal radiation is detected by narrowband $(630-800 \mathrm{~nm})$ and broadband $(350-800 \mathrm{~nm})$ filtered photo multiplier tube detectors. The signals from these are amplified to produce low and high gain signals, increasing the instruments detection resolution range. The SP2 therefore provides a measure of the total particle size distribution which can be segregated into non-absorbing (purely scattering) particles and incandescing (rBC-containing) particles. The time delay between the detection of scattering and incandescence signals from a single particle can be used as a proxy for the particle coating thickness since the coating must be ablated before the core can incandesce. The time delay is defined as the difference between the maxima in a particle's incandescence and elastic light scattering signals $\left(\tau_{\mathrm{d}}=t_{\text {incandescence }}-t_{\text {scatter }}\right)$ (Moteki and Kondo, 2007; Schwarz et al., 2006). A detailed intercomparison study of instruments measuring the black carbon content of well characterised soot particles demonstrated that the peak incandescence signal measured by the SP2 is proportional to black carbon mass and that for a given mass the incandescence signal is independent of particle morphology or mixing state (Slowik et al., 2007).

The SP2 was aligned and tested prior to the start of the experiment series and the instrument was calibrated daily before each series of experiments using glassy carbon spheres (Alpha Aesar, density $1.42 \mathrm{~g} \mathrm{~cm}^{-3}$ ) which were size selected using a DMA (TSI, model 3077), and polystyrene latex sphere test particles to verify the calibration and optical alignment of the instrument. As configured in this experiment, the SP2 typically detected single particles in a mass range of 7-370 fg, equivalent to particles with $0.19-0.73 \mu \mathrm{m}$ $\mathrm{rBC}$ core diameters, calculated from the particle mass assuming a rBC density of $1.8 \mathrm{~g} \mathrm{~cm}^{-3}$ however the CAST soot ( $\mathrm{rBC}$ plus associated material) may have densities of between 1.3 and $1.9 \mathrm{~g} \mathrm{~cm}^{-3}$ depending on OC content. The glassy carbon particle calibration covered a mass range $20-250 \mathrm{fg}(0.27-$ $0.65 \mu \mathrm{m}$ for soot density of $1.8 \mathrm{~g} \mathrm{~cm}^{-3}$ (Bond and Bergstrom, 2006). The detectable size range for purely scattering particles was $0.15-0.60 \mu \mathrm{m}$ diameter and PSL calibrations were performed over a size range from $0.20-0.60 \mu \mathrm{m}$. A detailed description of the data processing and analysis procedures developed for the University of Manchester SP2 is provided by Liu et al. (2010) and McMeeking et al. (2010).
Ice particle concentration and size was measured independently with an optical particle counter (OPC) and a Cloud Particle Imaging probe (CPI; SPEC, Model 1). The optical particle counter (WELAS model 2000, Palas GmbH) is sensitive to ice particles in the size range of $1-20 \mu \mathrm{m}$ in diamater and measured the size and number concentration from a vertical sample flow tube attached directly beneath the aerosol chamber. A CPI was also mounted directly below the aerosol chamber and used to measure the concentration and size distribution of large ice crystals with diameters, $D_{\mathrm{p}}>10 \mu \mathrm{m}$, and to identify their morphology. The CPI instrument and the analysis techniques used are the same as those described by Connolly et al. $(2007,2009)$.

The ice saturation ratio $\left(S_{\text {ice }}\right)$ was calculated from the water vapour pressure $e_{\mathrm{w}}$ that was measured in situ by a tuneable diode laser (TDL) absorption spectrometer. The instrument consists of a room temperature near-infrared tunable diode laser operating at a wavelength of $1370 \pm 2 \mathrm{~nm}$ and a White multipath cell with 23-99 m optical path (Ebert et al., 2005). The TDL system provides water vapour mixing ratio data with a time resolution of $1 \mathrm{~Hz}$, an accuracy of $\pm 5-10 \%$, and a resolution in the region of $15 \mathrm{ppb}$ as has been demonstrated during the international hygrometer intercomparison AquaVIT (Fahey et al., 2009). The water vapour saturation pressure with respect to ice was calculated according to the parameterisation of Murphy and Koop (2005).

\section{Experimental parameters and soot characterisation}

Two sets of ice cloud nucleation experiments using CAST and mini-CAST propane flame soot particles with the $\mathrm{OC}_{5}$, $\mathrm{OC}_{30}$ and $\mathrm{OC}_{70}$ content were carried out with and without a sulphuric acid (SA) coating. Seven experiments in total were conducted without SA coatings during the campaign, referred to hereafter as IN09 (March 2006). The parameters describing the experimental conditions and aerosol loadings for all the IN09 experiments are summarised in Table 1 along with the conditions at the onset of freezing. The onset of freezing conditions are defined as those where a given fraction of the test aerosol becomes ice active. In this work activation thresholds of $0.1 \%$ and $1 \%$ were initially used however given the low aerosol number concentrations for IN09 the $0.1 \%$ activation threshold may possibly be biased by background aerosol activation and so is excluded from the final discussions. Typical background activation concentrations from reference expansions were found to be approximately $0.5 \mathrm{~cm}^{-3}$. A further series of 11 experiments (referred to as the IN11 campaign, November 2007) studied the ice nucleation properties of mini-CAST propane flame soot particles with and without sulphuric acid coatings; the experimental conditions for the IN11 experiment are summarised in Table 1.

The $\mathrm{OC}_{5}$ and $\mathrm{OC}_{30}$ flame soot were characterised both prior to cloud expansion experiments at equilibrium in the 
Table 1. Parameters of AIDA ice cloud simulations. IN09 experiments were performed using CAST propane flame soot. $P_{0}$ is the AIDA pressure before pumping, $T_{\mathrm{g} 0}$ the AIDA gas temperature before pumping, $N_{\mathrm{a} 0}$ the AIDA aerosol number concentration before pumping. The onset of freezing for $0.1 \%$ and $1 \%$ of the aerosol population becoming ice active is given as a function of the AIDA gas temperature ( $T_{\mathrm{g}}$ ) and the saturation ratio with respect to ice and water $\left(S_{\mathrm{i}}\right.$ and $\left.S_{\mathrm{W}}\right)$.

\begin{tabular}{c|cccc|c|cc|ccc}
\hline & \multicolumn{4}{|c}{ Experiment Parameters } & \multicolumn{3}{c}{$0.1 \%$ activation } & \multicolumn{3}{c}{$1 \%$ activation } \\
\hline Experiment & Type & $P_{0}, \mathrm{hPa}$ & $T_{\mathrm{g} 0}, \mathrm{~K}$ & $N_{\mathrm{a} 0}, \mathrm{~cm}^{-3}$ & $T_{\mathrm{g}}, k$ & $S_{\mathrm{i}}$ & $S_{\mathrm{W}}$ & $T_{\mathrm{g}}, k$ & $S_{\mathrm{i}}$ & $S_{\mathrm{W}}$ \\
\hline IN09_08 & $\mathrm{OC}_{5}$ & 989.9 & 228.9 & 210 & 227.3 & 1.10 & 0.71 & 226.6 & 1.22 & 0.78 \\
IN09_09 & $\mathrm{OC}_{5}$ & 989.6 & 228.9 & 131 & 227.5 & 1.09 & 0.71 & 226.4 & 1.23 & 0.79 \\
IN09_18 & $\mathrm{OC}_{30}$ & 996.5 & 228.9 & 277 & 226.9 & 1.21 & 0.79 & 223.6 & 1.63 & 1.02 \\
IN09_19 & $\mathrm{OC}_{30}$ & 999.7 & 229.1 & 195 & 227.7 & 1.09 & 0.69 & 223.7 & 1.64 & 1.03 \\
IN09_20 & $\mathrm{OC}_{30}$ & 995.0 & 228.9 & 132 & 227.7 & 1.07 & 0.69 & 223.2 & 1.70 & 1.06 \\
IN09_21 & $\mathrm{OC}_{70}$ & 997.9 & 228.9 & 290 & 224.5 & 1.48 & 0.93 & 224.0 & 1.54 & 0.96 \\
IN09_22 & $\mathrm{OC}_{70}$ & 990.8 & 228.7 & 180 & 224.3 & 1.52 & 0.95 & 223.9 & 1.67 & 0.99 \\
\hline
\end{tabular}

AIDA chamber and during cloud expansion experiments using a PCVI. We treat the particles as $\mathrm{rBC}$ "cores" associated with organic coatings when interpreting the SP2 measurements. The top left and 2 nd left panels of Fig. 5 show the time delay, $\tau_{\mathrm{d}}$, between SP2 scattering and incandescence signals for the $\mathrm{OC}_{5}$ and $\mathrm{OC}_{30}$ soot particles prior to cloud expansion as a function of the black carbon core size. The $\mathrm{OC}_{5}$ and $\mathrm{OC}_{30}$ soot display significantly different time delay characteristics; the modal value of $\tau_{\mathrm{d}}$ for the $\mathrm{OC}_{5}$ soot is $0.6 \mu$ s at an $\mathrm{rBC}$ core mass equivalent diameter $\left(D_{\mathrm{BC}}\right)$ of $0.25 \mu \mathrm{m}$.

This is indicative of an undetectable coating and is similar to the time delays observed for uncoated calibration particles. In contrast the $\mathrm{OC}_{30}$ soot modal $\tau_{\mathrm{d}}$ is $5.8 \mu \mathrm{s}$ at $D_{\mathrm{BC}}=0.19 \mu \mathrm{m}$. Values of $\tau_{\mathrm{d}}=4.2 \mu \mathrm{s}$ are considered to be indicative of particles with a thick coating (Liu et al., 2010) thus the $\mathrm{OC}_{30}$ soot has a considerably thicker or less volatile coating than the $\mathrm{OC}_{5}$ soot. The $\mathrm{BC}$ core sizes for the $\mathrm{OC}_{5}$ were larger and more varied than the $\mathrm{OC}_{30}$ soot which may be due to the bulk of the mass residing in the core consisting of a chain aggregate fractal morphology whereas the $\mathrm{OC}_{30}$ soot has most of its mass residing in the coating. Previous work by Schnaiter et al. (2006) showed that soot of similar organic carbon content to the $\mathrm{OC}_{30}$ soot generated by CAST contained spheroidal particles of sizes up to $0.12 \mu \mathrm{m}$ in diameter which were presented individually or in small aggregates.

Analysis of the scattering and incandescence detected particles of the pre-expansion soot found that for the $\mathrm{OC}_{5}$ soot 1 in every 420 particles exhibited no incandescence. For the $\mathrm{OC}_{30}$ soot this was found to be approximately 1 in 21 particles. These ratios describe the entire detectable populations of particles sampled but do not necessarily represent to total population of particles outside either the incandescence $(\mathrm{DBC}=0.19-0.73 \mu \mathrm{m})$ or scattering $(D=0.15-0.6 \mu \mathrm{m}) \mathrm{de}-$ tection limits of the instrument.

The difference in $\tau_{\mathrm{d}}$ between the pre-expansion and residuals for the $\mathrm{OC}_{5}$ soot is small, $\tau_{\mathrm{d}}=0.4 \mu \mathrm{s}, D_{\mathrm{BC}}=0.28 \mu \mathrm{m}$
$\left(\Delta \tau_{\mathrm{d}}=-0.2 \mu \mathrm{s}, \Delta D_{\mathrm{BC}}=0.03 \mu \mathrm{m}\right)$, however the BC core size mode is broader and moves to larger mean sizes suggesting either that larger soot-core particles activate preferentially or that all sizes activate with equal efficiency but that the ice produced inertially scavenges additional unactivated particles which increases the size of the residual core. Very few $\mathrm{OC}_{30}$ soot particles are ice active, typically $2-3 \%$ of the population, resulting in poor counting statistics for the PCVI residual measurement in this case, thus no meaningful comparison between the pre-expansion and residual data can be made. Artefacts from incomplete evaporation of cloud particles in the PCVI are minimal for the $\mathrm{OC}_{5}$ soot; if the coating thickness was increased by incomplete evaporation it would be expected that there would be a significant shift in the modal value of $\tau_{\mathrm{d}}$ between the pre-expansion and residual particles. To test this several $\tau_{\mathrm{d}}$ probability densities of narrow core mass range ( $5 \mathrm{fg}$ ) were compared for the pre-expansion and residual soot where no significant modal variation was observed, however, there were some outliers spreading to high $\tau_{\mathrm{d}}$ in the residuals, suggesting that a minority of the residual particles have an increased coating thickness. If the PCVI were to remove volatiles from the coating then it would be expected that the modal value of $\tau_{\mathrm{d}}$ would decrease which is not consistent with the observations, however the SP2 may not be sufficiently sensitive to measure such a decrease. The $\tau_{\mathrm{d}}$ probability density integrated over the size range of the SP2 for the above cases is given in the 3 rd left panel of Fig. 5 where it can be seen that the $\mathrm{OC}_{5}$ and $\mathrm{OC}_{30} \tau_{\mathrm{d}}$ distributions are significantly different due to the difference in coating thickness. The $\mathrm{OC}_{5} \tau_{\mathrm{d}}$ distributions for the pre-expansion and residuals are similar and any differences are likely to be due to differences in the measured size distributions of each case. This is also observed in the $\mathrm{OC}_{5}$ incandescent mass probability distribution (3rd right panel, Fig. 5) where fewer low mass particles are observed in the residuals when compared to the pre-expansion sample, again suggesting that the larger soot particles are preferentially activated. Previous studies have observed similar phenomena 

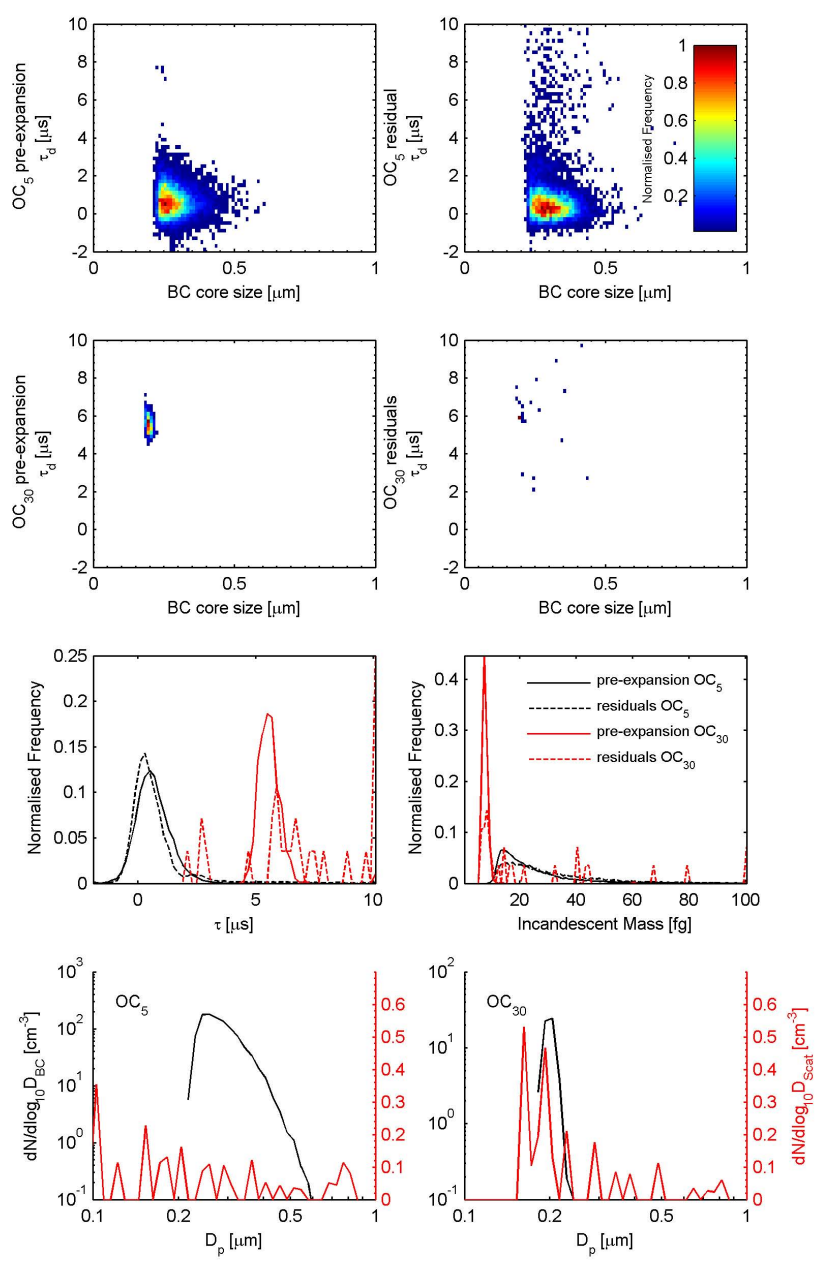

Fig. 5. Characterisation of Soot Core Size and Coating Thickness of the $\mathrm{OC}_{5}$ and $\mathrm{OC}_{30}$ flame soot. Top panels display the normailized frequency of soot as a function of BC core diameter and $\tau_{\mathrm{d}}$ for the $\mathrm{OC}_{5}$ soot sampled at equilibrium in the AIDA chamber prior to a cloud expansion (left) and cloud particle residuals sampled during a cloud expansion using a PCVI (right). The frequency is normailized to the maximum observed frequency in the averaged sample. 2nd row panels display the same for the $\mathrm{OC}_{30}$ soot. 3 rd row panels display the $\tau_{\mathrm{d}}$ probability density (left) and incandescent mass probability density (right) at all $\mathrm{BC}$ score sizes for the $\mathrm{OC}_{5}$ and $\mathrm{OC}_{30}$ soot sampled pre-expansion at equilibrium and from PCVI residuals. Bottom panels display the optical size distributions of the preexpansion $\mathrm{OC}_{5}$ (left) and $\mathrm{OC}_{30}$ (right) soot; black line is for $\mathrm{BC}$ containing particles (left axis) and the red line is for purely scattering particles only (right axis). Note different scales. The frequency of $\tau_{\mathrm{d}}$ and incandescent mass are normalized by sample duration.

for dust particles; Archuleta et al. (2005) reported size dependent ice activation efficiencies for several mineral dusts where they noted that larger particles consistently nucleated ice at lower humidity than smaller particles at the same temperature. Möhler et al. (2006) also showed that larger dust particles are more ice active than smaller particles owing to their larger surface area on which nucleation can occur. The bottom panels of Fig. 5 show the optical particle size distributions for the pre-expansion aerosol containg $\mathrm{rBC}$ (black) and without $\mathrm{rBC}$ (red, purely scattering particles). It can be seen that the modal diameters are in agreement with the SMPS measurements and that very few purely scattering particles are observed.

\subsection{Influence of organic carbon content}

A series of cloud simulation experiments starting at an initial temperature of $228 \mathrm{~K}$ and with constant pumping rates were performed using the three test soots. The left hand column of Fig. 6 shows a time series of temperature, $(T)$, pressure, $(P)$, supersaturation with respect to ice $\left(S_{\text {ice }}\right)$ and water $\left(S_{\text {water }}\right)$, ice number concentration $\left(N_{\text {ice }}\right)$ measured with the WELAS OPC (black line) and CPI (blue line), and the percentage of the aerosol population that has become ice active for the $\mathrm{OC}_{5}$ soot. For the $\mathrm{OC}_{5}$ soot (experiment IN09_08) the onset of freezing occurs well below water saturation suggesting the particles are active as deposition freezing nuclei; approximately $25 \%$ of the soot particles were observed to activate during this experiment. From the time series of particle concentrations a formation rate of $\sim 1.20 \mathrm{~cm}^{-3} \mathrm{~s}^{-1}$ was subsequently calculated over the period from the initiation of the ice phase to the maximum observed ice number. At the onset of freezing the ratio of $\mathrm{rBC}$ to purely scattering particles detected by the SP2 in the residual aerosol was approximately 7 , indicating that the ice active aerosol largely contains incandescent material, thus the $\mathrm{OC}_{5}$ soot is ice active. A subsequent expansion on the same test soot under similar conditions (IN09_09) yielded a similar onset of freezing for the $1 \%$ ice activation threshold within experimental error. When compared to the onset of freezing for pure sulphuric acid solution droplets Möhler et al. (2003) it can be seen that the $\mathrm{OC}_{5}$ flame soot acts as a deposition nucleus at much lower $S_{\text {ice }}$ than is required for homogeneous freezing of solution droplets at the same temperature.

The $\mathrm{OC}_{30}$ flame soot (experiment IN09_18, Fig. 6, middle column) displays somewhat different nucleation characteristics to the $\mathrm{OC}_{5}$ soot. The $1 \%$ ice active onset of freezing occurs above water saturation with a significantly lower ice particle formation rate of $\sim 0.05 \mathrm{~cm}^{-3} \mathrm{~s}^{-1}$ with only $1 \%$ of the aerosol being ice active. The ratio of incandescent particles to scattering particles in the residuals also is low (20-60\%) although the counting statistics are limited. Subsequent expansions on the same test soot (IN09_19 and IN09_20) yielded a similar onset of freezing for the $1 \%$ ice activation threshold within experimental error.

The right hand column of Fig. 6 shows the time series of the $\mathrm{OC}_{70}$ soot experiment (IN09_21). Similar to the $\mathrm{OC}_{30}$ experiment, the onset of freezing occurs near water saturation, however, the formation rate is significantly higher at $\sim 0.19 \mathrm{~cm}^{-3} \mathrm{~s}^{-1}$. In this case $3-5 \%$ of the aerosol became activated. The majority of residual particles do not 

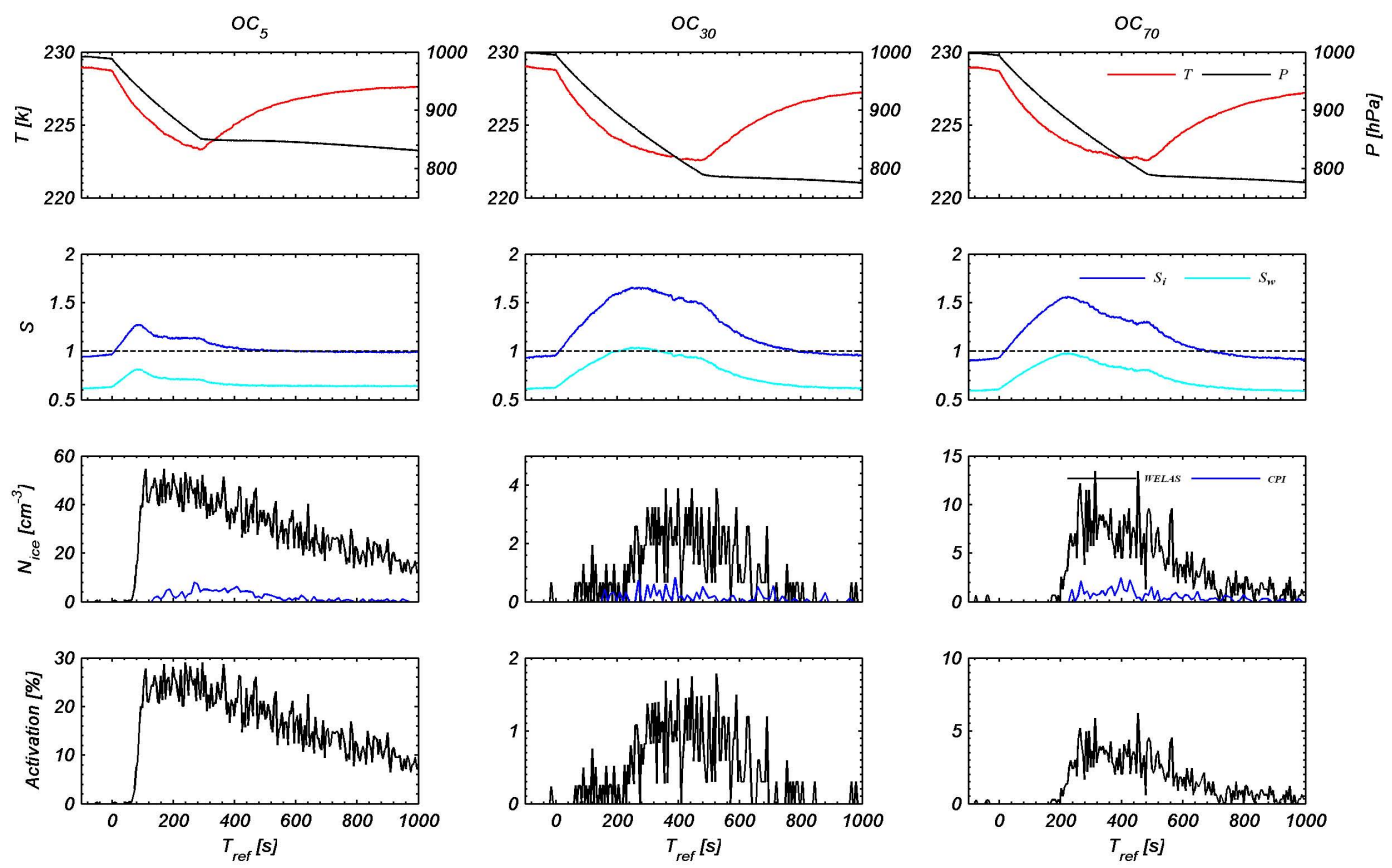

Fig. 6. Time series of temperature $(T)$, pressure $(P)$, saturation ratio with respect to ice and water $(S)$, ice crystal number concentration $\left(N_{\text {ice }}\right)$ and percentage of the aerosol population active in the ice phase for the $\mathrm{OC}_{5}, \mathrm{OC}_{30}$ and $\mathrm{OC}_{70}$ flame soot.

incandesce and only small cores are observed with low refractory BC mass fraction. Similar to previous experiments, subsequent expansion experiments on the same soot did not yield significant differences in the onset of freezing.

The above experiments on the uncoated soot are summarised in Fig. 7 where the onset of freezing is shown as a function of temperature and ice saturation ratio. It can clearly be seen that the $\mathrm{OC}_{5}$ soot became ice active as deposition nuclei below water saturated conditions whereas the $\mathrm{OC}_{30}$ and $\mathrm{OC}_{70}$ soots required water saturation for ice nucleation to occur. Soot types with IN thresholds above the water saturation line can be considered as completely unimportant for heterogeneous ice nucleation in the atmosphere.

\subsection{Influence of sulphuric acid coating}

The second series of experiments (IN11) examined how the ice nucleating behaviour of mini-CAST propane soot particles was altered by the addition of a sulphuric acid coating. It was found that the addition of the coating acted to shift the freezing threshold of $\mathrm{OC}_{30}$ soot to higher ice saturation ratios than were necessary for the uncoated soot to become ice active as is shown in Fig. 9. The uncoated $\mathrm{OC}_{30}$ flame soot activated to form ice below water saturation by deposition nucleation in a similar fashion to the previous series of experiments. When a sulphuric acid coating was applied the onset of freezing for $0.1 \%$ of the aerosol population (IN11_24, Fig. 9) occured at conditions typical of the homogeneous freezing sulphuric acid as characterised by Koop et al. (2000). The time series of ice crystal number concentration for the $\mathrm{OC}_{30}$ soot with sulphuric acid coating is shown in the left column of Fig. 8 where it can be seen that there is a sharp increase in ice crystal number concentration as measured by the WELAS shortly after the onset of freezing. The $\mathrm{RH}$ at the onset of freezing along with the ice formation rate $\left(2.18 \mathrm{~cm}^{-3} \mathrm{~s}^{-1}\right)$ indicates that ice is mainly formed by the homogeneous freezing of sulphuric acid mixed with organics from the flame soot. However, a contribution from immersion freezing cannot be ruled out.

The $\mathrm{OC}_{80}$ mini-CAST soot was found to be inactive when uncoated. Ice activation behaviour was not observed until $S_{\mathrm{i}}$ values of $2.2-2.38\left(T_{\mathrm{g}}=219.4-218.6 \mathrm{~K}, S_{\mathrm{w}}\right.$ in excess of 1.3) was achieved, considerably higher than the results reported for IN09 using the CAST burner. The reason for this is unclear; possible explanations are that the generated soot is extremely hydrophobic or that the organic coating has undergone a glassy transition resulting in ice crystal growth being significantly impeded which has recently been independently demonstrated by Zobrist et al. (2008) and Murray (2008). When the $\mathrm{OC}_{80}$ soot is coated with sulphuric acid the onset of freezing occurs slightly above the homogeneous freezing threshold for sulphuric acid suggesting that similar to the $\mathrm{OC}_{30}$ case, the homogeneous freezing of the mixed coating is the dominant process.

The uncoated $\mathrm{OC}_{90}$ mini-CAST soot became ice active at water saturation similar to the $\mathrm{OC}_{70} \mathrm{CAST}$ soot. Subsequent expansions on the same soot showed that significant IN activity required water saturation. The addition of a sulphuric 
Table 2. Same as Table 1 but using mini-CAST propane flame soot. Values in italics are extrapolated from the $0.1 \%$ activation data.

\begin{tabular}{|c|c|c|c|c|c|c|c|c|c|c|}
\hline & \multicolumn{4}{|c|}{ Experiment Parameters } & \multicolumn{3}{|c|}{$0.1 \%$ activation } & \multicolumn{3}{|c|}{$1 \%$ activation } \\
\hline Experiment & Type & $P_{0}, \mathrm{hPa}$ & $T_{\mathrm{g} 0}, \mathrm{~K}$ & $N_{\mathrm{a} 0}, \mathrm{~cm}^{-3}$ & $T_{\mathrm{g}}, k$ & $S_{\mathrm{i}}$ & $S_{\mathrm{W}}$ & $T_{\mathrm{g}}, k$ & $S_{\mathrm{i}}$ & $S_{\mathrm{W}}$ \\
\hline IN11_20 & $\mathrm{OC}_{30}$ & 997.1 & 228.8 & 1100 & 225.1 & 1.32 & 0.84 & 224.8 & 1.36 & 0.86 \\
\hline IN11_21 & $\mathrm{OC}_{30}$ & 995.2 & 228.8 & 775 & 224.8 & 1.38 & 0.87 & 224.4 & 1.43 & 0.90 \\
\hline IN11_22 & $\mathrm{OC}_{30}$ & 995.3 & 228.8 & 570 & 224.5 & 1.42 & 0.89 & 224.2 & 1.47 & 0.92 \\
\hline IN11_24 & $\mathrm{OC}_{30} \mathrm{w} / \mathrm{SA}$ & 999.1 & 228.8 & 1500 & 224.0 & 1.47 & 0.92 & 223.9 & 1.48 & 0.93 \\
\hline IN11_25 & $\mathrm{OC}_{30} \mathrm{w} / \mathrm{SA}$ & 1000.2 & 228.8 & 1090 & 224.9 & 1.38 & 0.87 & - & - & - \\
\hline IN11_26 & $\mathrm{OC}_{90}$ & 1013.1 & 228.5 & 1170 & 222.2 & $>1.6$ & $>1.0$ & - & - & - \\
\hline IN11_27 & $\mathrm{OC}_{90}$ & 1013.0 & 228.3 & 780 & 220.2 & $>2.2$ & $>1.3$ & - & - & - \\
\hline IN11_28 & $\mathrm{OC}_{90}$ & 1013.2 & 228.3 & 525 & 218.5 & 2.48 & 1.50 & - & - & - \\
\hline IN11_30 & $\mathrm{OC}_{90} \mathrm{w} / \mathrm{SA}$ & 1015.1 & 228.1 & 1380 & 223.4 & 1.47 & 0.92 & 223.2 & 1.48 & 0.92 \\
\hline IN11_31 & $\mathrm{OC}_{90} \mathrm{w} / \mathrm{SA}$ & 1015.1 & 228.1 & 950 & 223.5 & 1.47 & 0.92 & 223.1 & 1.52 & 0.94 \\
\hline IN11_32 & $\mathrm{OC}_{90} \mathrm{w} / \mathrm{SA}$ & 1015.2 & 228.1 & 610 & 223.3 & 1.49 & 0.93 & 223.1 & 1.51 & 0.94 \\
\hline IN11_34 & $\mathrm{OC}_{80} \mathrm{w} / \mathrm{SA}$ & 1010.7 & 228.0 & 1210 & 223.1 & 1.51 & 0.94 & 222.7 & 1.56 & 0.97 \\
\hline IN11_35 & $\mathrm{OC}_{80} \mathrm{w} / \mathrm{SA}$ & 1007.3 & 228.0 & 860 & 223.1 & 1.53 & 0.95 & 222.9 & 1.56 & 0.97 \\
\hline IN11_37 & $\mathrm{OC}_{80}$ & 1002.0 & 228.2 & 1360 & 219.4 & $>2.2$ & $>1.3$ & - & - & - \\
\hline IN11_38 & $\mathrm{OC}_{80}$ & 1000.4 & 228.0 & 930 & 219.2 & 2.3 & 1.38 & - & - & - \\
\hline IN11_39 & $\mathrm{OC}_{80}$ & 1002.2 & 228.1 & 620 & 218.6 & 2.38 & 1.43 & - & - & - \\
\hline
\end{tabular}

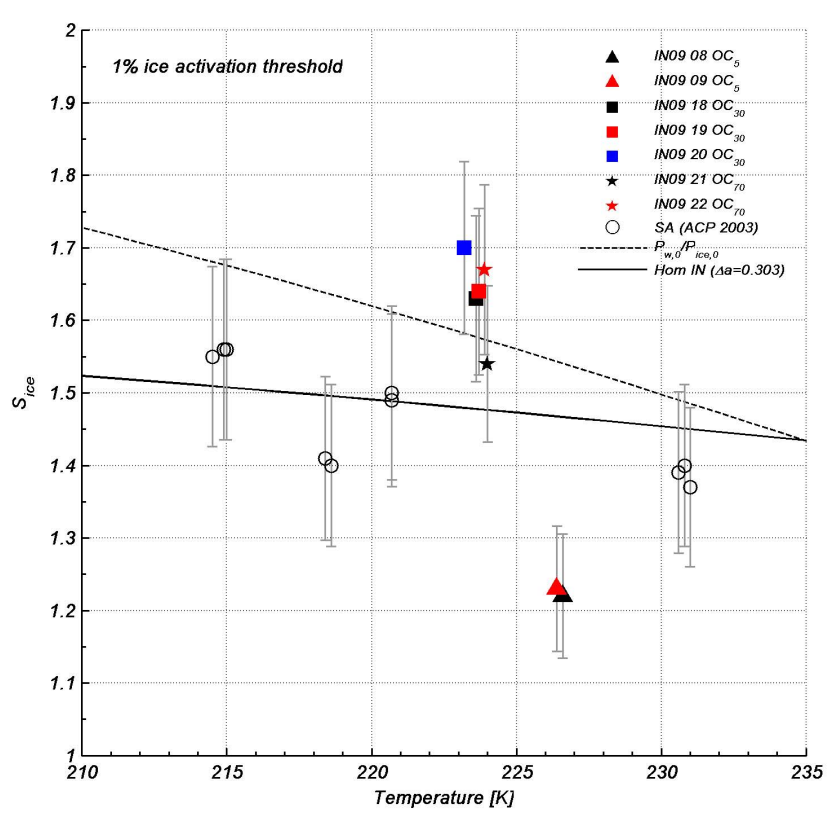

Fig. 7. Summary of $T$ and $S_{\text {ice }}$ for the onset of freezing for the $\mathrm{OC}_{5}$, $\mathrm{OC}_{30}$ and $\mathrm{OC}_{70}$ flame soot particles during IN09 experiments. The dashed line indicates water saturation as given by Murphy and Koop (2005). For comparison the homogeneous freezing of pure sulphuric acid droplets are shown (ACP 2003) from previous AIDA studies Möhler et al. (2003) along with the homogeneous freezing threshold, (Hom IN) of supercooled solution droplets Koop et al. (2000), indicated by the solid line, where $\Delta a$ is the fitting parameter used as described in Möhler et al. (2003) to calculate the homogeneous freezing threshold. acid coating required conditions for the onset of freezing that were similar to those for homogeneous freezing of sulphuric acid, again suggesting homogeneous freezing to be the dominant mode. The results of the above experiments are summarised in Fig. 9 where the onset of freezing is shown as a function of temperature and ice saturation ratio. The mean conditions at the onset of freezing are given in Table 2. The addition of a sulphuric acid coating acts to impede the ease with which the mini-CAST OC 30 flame soot will become ice active when comparing IN11_20 to IN11_24, however for the second consecutive expansion on the test soot (IN11_22 and IN11_25) little change was observed. The addition of a sulphuric acid coating to the $\mathrm{OC}_{80}$ and $\mathrm{OC}_{90}$ mini-CAST soots resulted in a significant reduction in the threshold of the onset of freezing, making them more active IN.

\section{Summary and conclusions}

The critical saturation ratios for the onset of freezing of propane flame soot particles with and without sulphuric acid coatings as a function of organic carbon content were investigated. Ice initiation was achieved in cloud simulation expansion experiments with cooling rates between -0.7 to $-2.1 \mathrm{~K} \mathrm{~min}^{-1}$. For uncoated CAST soot, ice nucleation occured at a minimum threshold of $S_{\text {ice }} \sim 1.22$ at $T=226.6 \mathrm{~K}$ for the $\mathrm{OC}_{5}$ test soot by deposition freezing. The $\mathrm{OC}_{30}$ case required supersaturation with respect to water for ice formation to occur as did the $\mathrm{OC}_{70}$ flame soot case. This suggests that either the higher OC flame soots activate by condensation freezing or only act as freezing nuclei after liquid droplet activation, which is in agreement with previous studies by DeMott (1990) using flame soot particles. It is suggested that 

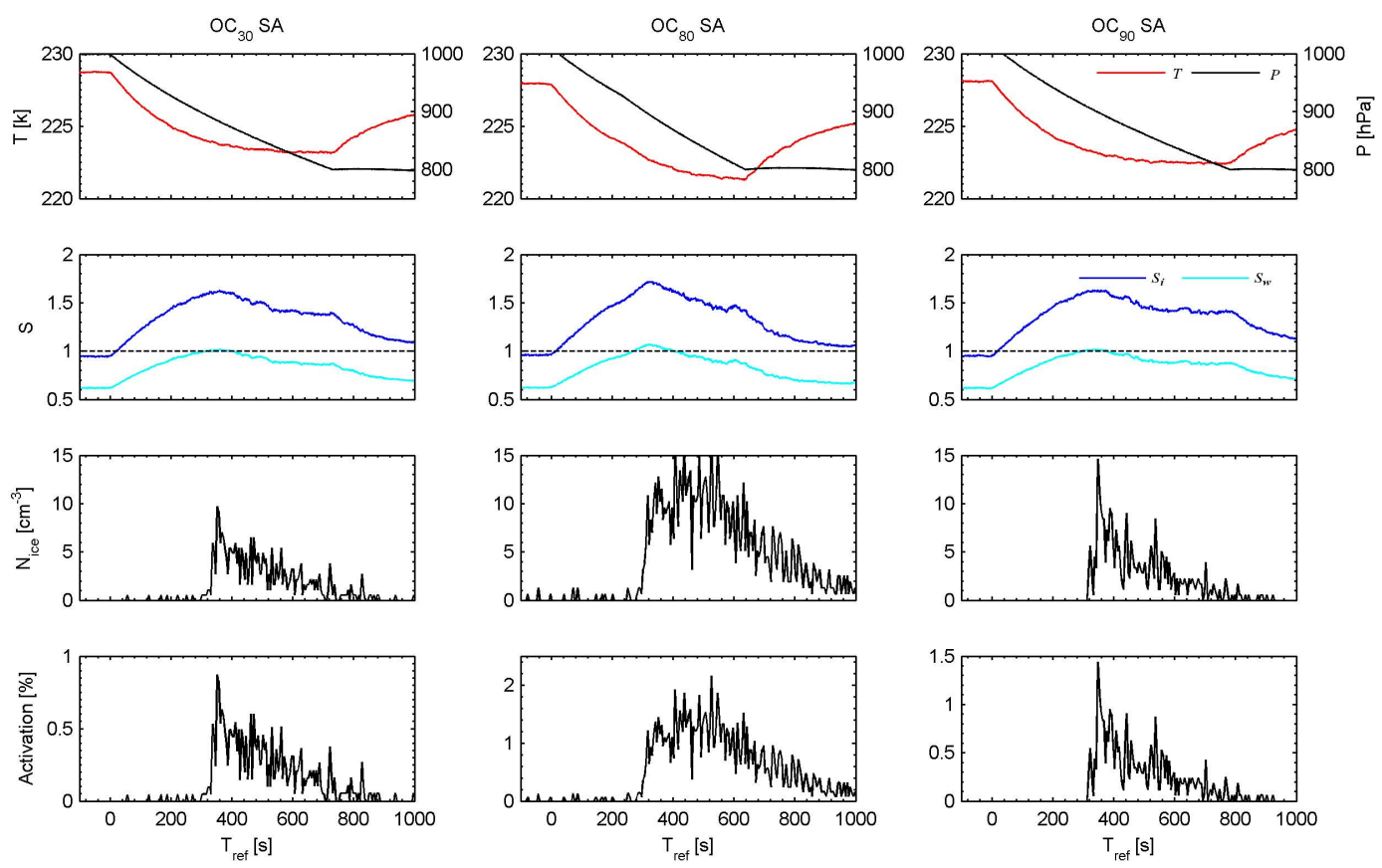

Fig. 8. Same as Fig. 6 but for mini-CAST $\mathrm{OC}_{30}, \mathrm{OC}_{80}$ and $\mathrm{OC}_{90}$ flame soot with sulphuric acid coating.

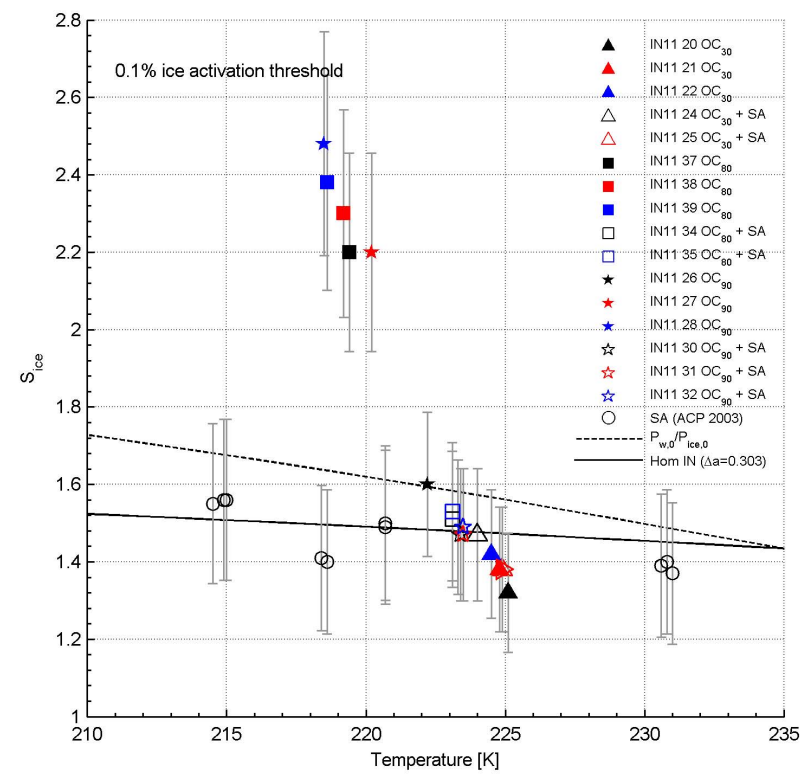

Fig. 9. Onset of freezing where $0.1 \%$ of the aerosol population become ice active for $\mathrm{OC}_{30}, \mathrm{OC}_{80}$ and $\mathrm{OC}_{90}$ flame soot with (unfilled markers) and without (filled markers) a sulphuric acid coating. Dashed line is water saturation; water saturation pressure parameterisation given by Murphy and Koop (2005). For comparison the homogeneous freezing of pure sulphuric acid droplets are shown from previous AIDA studies Möhler et al. (2003), labeled ACP 2003, along with the homogeneous freezing threshold of supercooled solution droplets Koop et al. (2000), indicated by the solid line. the variation in ice activation threshold may be due to the different soot core sizes with larger cores exhibiting lower thresholds.

The addition of a sulphuric acid coating was observed to alter the ice nucleation threshold for all of the test soot. For the mini-CAST $\mathrm{OC}_{30}$ soot the coating acted to increase the activation threshold for the initial expansion, effectively making it a less active ice nucleus. This is in agreement with Möhler et al. (2005a). For the subsequent expansion on the coated $\mathrm{OC}_{30}$ soot the coating acted to slightly decrease the activation threshold when compared to the subsequent expansion on the uncoated soot. The mechanism for this is unclear.

The addition of sulphuric acid coatings to the mini-CAST $\mathrm{OC}_{80}$ and $\mathrm{OC}_{90}$ soots acted to significantly reduce the threshold required for ice activation as the particles undergo homogeneous freezing. This is in agreement with the work of DeMott et al. (1999), who showed that addition of multiple layers of $\mathrm{H}_{2} \mathrm{SO}_{4}$ to Degussa soot would reduce the $\mathrm{RH}_{w}$ required for ice nucleation by as much as $10 \%$. This is contrary however to the result of Möhler et al. (2005a) who showed that spark generator soot became less efficient IN when coated with sulphuric acid. However, a key point here is that the uncoated spark generator soot was shown to be a highly efficient IN, which is not true of the $\mathrm{OC}_{80}$ and $\mathrm{OC}_{90}$ flame soot used here. The Möhler et al. (2005a) study notes that there is a discrepancy between their findings and the DeMott et al. (1999) study and states that there may be a relationship between the ice nucleation efficiency of the soot and how it behaves when coated with sulphuric 
acid. Recently Koehler et al. (2009) demonstrated that the hygroscopic charachter of soot was important in detemining its freezing characteristics. They found that hydrophobic soot particles required high supersaturation for ice activation, where as hydrophilic soot were considerably better IN. They also noted that the addition of hygroscopic material always moved the onset of freezing towards the conditions typical of homgeneous freezing which is in agreement with the findings presented in this paper. This result demonstrates that it is important to know the organic carbon content of soot and its mixing state with sulphuric acid in order to fully assess its impact as an ice nucleus and further investigation is clearly required.

It has been shown that propane flame soot acts as an efficient deposition mode IN if it has a sufficiently low organic carbon content and uncoated. Should the soot be similar to those types found in aircraft exhaust emissions then they may be significant for so-called soot-induced cirrus as described by Jensen and Toon (1997) and Kärcher et al. (2007), where the exhaust soot disperses to form or modify cirrus cloud. Modelling studies by Kärcher (2004) showed that heterogeneous freezing can significantly dehydrate the tropical tropopause if the IN present freeze at low supersaturations $\left(\mathrm{RH}_{i} \leq 130\right)$ or are at least present in abundance $\left(N_{\mathrm{p}} \geq 101^{-1}\right)$. The minimum organic carbon content soot satisfies these criteria, allowing this soot to potentially alter the moisture budget in this region significantly (Kärcher, 2004). However, it is important to know the mixing state as coatings may act to reduce soot ice activity the conditions specified by the Kärcher study. Studies in the upper troposphere and lower stratosphere by Schwarz et al. using an SP2 found that $60-80 \%$ of the black carbon was internally mixed with other material (Schwarz et al., 2008). Liu et al. (2010) reported that $40 \pm 15 \%$ of observed BC particles in the free troposphere over Switzerland were mixed with large amounts of non-refractory materials present as a thick coating surrounding the $\mathrm{BC}$ core. Given the findings of this paper, such coatings would act to reduce the efficiency of $\mathrm{OC}_{5}$ soot as an ice nuclei such that they may not activate at $\mathrm{RH}_{i} \leq 130$.

Acknowledgements. This work was funded by the NERC APPRAISE programme, grant number NE/E01125X/1. Part of the AIDA work was funded within the European Union Integrated Project SCOUT-O3. Technical support by the AIDA team is gratefully acknowledged. Instrumentation and instrument scientist support provided by NERC National Centre for Atmospheric Science (NCAS) and the NCAS Facility for Ground Based Measurements (FGAM). I. Crawford was supported by a NERC studentship NER/S/A/2004/12355.

Edited by: L. M. Russell

\section{References}

Archuleta, C. M., DeMott, P. J., and Kreidenweis, S. M.: Ice nucleation by surrogates for atmospheric mineral dust and mineral dust/sulfate particles at cirrus temperatures, Atmos. Chem. Phys., 5, 2617-2634, doi:10.5194/acp-5-2617-2005, 2005.

Baumgardner, D., Kok, G., and Raga, G.: Warming of the Arctic lower stratosphere by light absorbing particles, Geophys. Res. Lett., 31, L06117, doi:10.1029/2003GL018883, 2004.

Baumgardner, D., Subramanian, R., Twohy, C., Stith, J., and Kok, G.: Scavenging of black carbon by ice crystals over the northern Pacific, Geophys. Res. Lett., 35, L22815, doi:10.1029/2008GL035764, 2008.

Benz, S., Megahed, K., Möhler, O., Saathoff, H., Wagner, R., and Schurath, U.: T-dependent rate measurements of homogeneous ice nucleation in cloud droplets using a large atmospheric simulation chamber, J. Photochem. Photobiol. A, 176, 208-217, 2005.

Bond, T. and Bergstrom, R.: Light Absorption by Carbonaceous Particles: An Investigative Review, Aerosol Sci. Tech., 40, 2767, doi:10.1080/02786820500421521, 2006.

Boulter, J., Cziczo, D., Middlebrook, A., Thomson, D., and Murphy, D.: Design and Performance of a Pumped Counterflow Virtual Impactor, Aerosol Sci. Tech., 40, 969-976, 2006.

Connolly, P. J., Flynn, M. J., Ulanowski, Z., Choularton, T. W., Gallagher, M. W., and Bower, K. N.: Calibration of the Cloud Particle Imager Probes Using Calibration Beads and Ice Crystal Analogs: The Depth of Field, J. Atmos. Ocean. Tech., 24, 18601879, 2007.

Connolly, P. J., Möhler, O., Field, P. R., Saathoff, H., Burgess, R., Choularton, T., and Gallagher, M.: Studies of heterogeneous freezing by three different desert dust samples, Atmos. Chem. Phys., 9, 2805-2824, doi:10.5194/acp-9-2805-2009, 2009.

DeMott, P.: An Exploratory Study of Ice Nucleation by Soot Aerosols, J. Appl. Meteorol., 29, 1072-1079, 1990.

DeMott, P. J., Rogers, D. C., and Kreidenweis, S. M.: The susceptibility of ice formation in upper tropospheric clouds to insoluble aerosol components, J. Geophys. Res.-Atmos., 102, 1957519584, 1997.

DeMott, P. J., Rogers, D. C., Kreidenweis, S. M., Chen, Y., Twohy, C. H., Baumgardner, D., Heymsfield, A. J., and Chan, K. R.: The role of heterogeneous freezing nucleation in upper tropospheric clouds: Inferences from SUCCESS, Geophys. Res. Lett., 25, 1387, doi:10.1029/97GL03779, 1998.

DeMott, P., Chen, Y., Kreidenweis, S., Rogers, D., and Sherman, D.: Ice formation by black carbon particles, J. Geophys. Res. Lett., 26, 2429-2432, 1999.

Diehl, K. and Mitra, S. K.: A laboratory study of the effects of a kerosene-burner exhaust on ice nucleation and the evaporation rate of ice crystals, Atmos. Environ., 32, 3145-3151, 1998.

Dymarska, M., Murray, B., Sun, L., Eastwood, M., Knopf, D., and Bertram, A.: Deposition ice nucleation on soot at temperatures relevant for the lower troposphere, J. Geophys. Res., 111, D04204, doi:10.1029/2005JD006627, 2006.

Ebert, V., Teichert, H., Giesemann, C., Saathoff, H., and Schurath, U.: Fiber-coupled in-situ laser absorption spectrometer for the selective detection of water vapour traces down to the ppb-level, Tech. Mess., 72, 23-30, 2005. 
Fahey, D., Gao, R. S., and Moehler, O.: Summary of the AquaVIT Water Vapour Intercomparison: Static Experiments, 2009.

Field, P., Cotton, R. J., Johnson, D., Noone, K., Glantz, P., Kaye, P. H., Hirst, E., Greenaway, R. S., Jost, C., Gabriel, R., Reiner, T., Andreae, M., Saunders, C. P. R., Archer, A., Choularton, T., Smith, M., Brooks, B., Hoell, C., Bandy, B., and Heymsfield, A.: Ice nucleation in orographic wave clouds: Measurements made during INTACC, Q. J. Roy. Meteorol. Soc., 127, 14931512, 2001.

Gierens, K.: On the transition between heterogeneous and homogeneous freezing, Atmos. Chem. Phys., 3, 437-446, doi:10.5194/acp-3-437-2003, 2003.

Gorbunov, B., Baklanov, A., Kakutkina, N., Windsor, H. L., and Toumi, R.: Ice nucleation on soot particles, J. Aerosol Sci., 32, 199-215, http://www.sciencedirect.com/science/article/ B6V6B-423986B-3/2/b443bace3c62b8e2cab376e51a1f879e, 2001.

Haag, W., Kärcher, B., Ström, J., Minikin, A., Lohmann, U., Ovarlez, J., and Stohl, A.: Freezing thresholds and cirrus cloud formation mechanisms inferred from in situ measurements of relative humidity, Atmos. Chem. Phys., 3, 1791-1806, doi:10.5194/acp3-1791-2003, 2003.

Heymsfield, A. J. and Miloshevich, L. M.: Homogeneous Ice Nucleation and Supercooled Liquid Water in Orographic Wave Clouds, J. Atmos. Sci., 50, 2335-2353, 1993.

Heymsfield, A. J. and Sabin, R. M.: Cirrus Crystal Nucleation by Homogeneous Freezing of Solution Droplets, J. Atmos. Sci., 46, 2252-2264, 1989.

Heymsfield, A. J., Miloshevich, L. M., Twohy, C., Sachse, G., and Oltmans, S.: Upper-tropospheric relative humidity observations and implications for cirrus ice nucleation, Geophys. Res. Lett., 25, 1343, doi:10.1029/98GL01089, 1998.

Jensen, E. and Toon, O.: The potential impact of soot particles from aircraft exhaust on cirrus clouds, Geophys. Res. Lett., 24, 249252, 1997.

Jensen, E. J., Toon, O. B., Tabazadeh, A., Sachse, G. W., Anderson, B. E., Chan, K. R., Twohy, C. W., Gandrud, B., Aulenbach, S. M., Heymsfield, A., Hallett, J., and Gary, B.: Ice nucleation processes in upper tropospheric wave-clouds observed during SUCCESS, Geophys. Res. Lett., 25, 1363, doi:10.1029/98GL00299, 1998.

Kärcher, B.: A Parameterization of cirrus cloud formation: Homogeneous freezing including effects of aerosol size, J. Geophys. Res., 107, 4698, doi:10.1029/2001JD001429, 2002.

Kärcher, B.: Cirrus clouds in the tropical tropopause layer: Role of heterogeneous ice nuclei, Geophys. Res. Lett., 31, 1-5, doi:10.1029/2004GL019774, 2004.

Kärcher, B. and Lohmann, U.: A parameterization of cirrus cloud formation: Heterogeneous freezing, J. Geophys. Res., 108, 4402, doi:10.1029/2002JD003220, 2003.

Kärcher, B., Möhler, O., DeMott, P. J., Pechtl, S., and Yu, F.: Insights into the role of soot aerosols in cirrus cloud formation, Atmos. Chem. Phys., 7, 4203-4227, doi:10.5194/acp-7-4203-2007, 2007.

Koehler, K. A., DeMott, P. J., Kreidenweis, S. M., Popovicheva, O. B., Petters, M. D., Carrico, C. M., Kireeva, E. D., Khokhlova, T. D., and Shonija, N. K.: Cloud condensation nuclei and ice nucleation activity of hydrophobic and hydrophilic soot particles, Phys. Chem. Chem. Phys., 11, 7906-7920,
doi:10.1039/B905334B, 2009.

Koop, T., Luo, B. P., Tsias, A., and Peter, T.: Water activity as the determinant for homogeneous ice nucleation in aqueous solutions, Nature, 406, 611-614, 2000.

Liu, D., Flynn, M., Gysel, M., Targino, A., Crawford, I., Bower, K., Choularton, T., Jurányi, Z., Steinbacher, M., Hüglin, C., Curtius, J., Kampus, M., Petzold, A., Weingartner, E., Baltensperger, U., and Coe, H.: Single particle characterization of black carbon aerosols at a tropospheric alpine site in Switzerland, Atmos. Chem. Phys., 10, 7389-7407, doi:10.5194/acp-10-7389-2010, 2010.

Lohmann, U.: A glaciation indirect aerosol effect caused by soot aerosols, Geophys. Res. Lett., 29, 1052, doi:10.1029/2001GL014357, 2002.

Lohmann, U. and Feichter, J.: Global indirect aerosol effects: a review, Atmos. Chem. Phys., 5, 715-737, doi:10.5194/acp-5-7152005, 2005.

Lohmann, U.: First interactive simulations of cirrus clouds formed by homogeneous freezing in the ECHAM general circulation model, J. Geophys. Res.-Atmos., 107, 4105, doi:10.1029/2001JD000767, 2002.

Marti, J. and Mauersberger, K.: A survey and new measurements of ice vapour pressure at temperatures between 170 and $250 \mathrm{~K}$, Gephys. Res. Lett., 5, 363-366, 1993.

McMeeking, G. R., Hamburger, T., Liu, D., Flynn, M., Morgan, W. T., Northway, M., Highwood, E. J., Krejci, R., Allan, J. D., Minikin, A., and Coe, H.: Black carbon measurements in the boundary layer over western and northern Europe, Atmos. Chem. Phys., 10, 9393-9414, doi:10.5194/acp-10-9393-2010, 2010.

Möhler, O., Stetzer, O., Schaefers, S., Linke, C., Schnaiter, M., Tiede, R., Saathoff, H., Krämer, M., Mangold, A., Budz, P., Zink, P., Schreiner, J., Mauersberger, K., Haag, W., Kärcher, B., and Schurath, U.: Experimental investigation of homogeneous freezing of sulphuric acid particles in the aerosol chamber AIDA, Atmos. Chem. Phys., 3, 211-223, doi:10.5194/acp-3-211-2003, 2003.

Möhler, O., Büttner, S., Linke, C., Schnaiter, M., Saathoff, M., Stetzer, O., Wagner, R., Kramer, M., Mangold, A., V. Ebert, V., and Schurath, U.: Effect of sulfuric acid coating on heterogeneous ice nucleation by soot aerosol particles, J. Geophys. Res., 110, D11210, doi:10.1029/2004JD005169, 2005a.

Möhler, O., Linke, C., Saathoff, H., Schnaiter, M., Wagner, R., Mangold, A., Krämer, M., and Schurath, U.: Ice nucleation on flame soot aerosol of different organic carbon content, Meteorol. Z., 14, 477-484, doi:10.1127/0941-2948/2005/0055, 2005b.

Möhler, O., Field, P. R., Connolly, P., Benz, S., Saathoff, H., Schnaiter, M., Wagner, R., Cotton, R., Krämer, M., Mangold, A., and Heymsfield, A. J.: Efficiency of the deposition mode ice nucleation on mineral dust particles, Atmos. Chem. Phys., 6, 3007-3021, doi:10.5194/acp-6-3007-2006, 2006.

Möhler, O., Benz, S., Saathoff, H., Schnaiter, M., Wagner, R., Schneider, J., Walter, S., Ebert, V., and Wagner, S.: The effect of organic coating on the heterogeneous ice nucleation efficiency of mineral dust aerosols, Environ. Res. Lett., 3, 025007 , doi:10.1088/1748-9326/3/2/025007, 2008.

Moteki, N. and Kondo, Y.: Effects of Mixing State on Black Carbon Measurements by Laser-Induced Incandescence, Aerosol Sci. Tech., 41, 398-417, 2007.

Murphy, D. M. and Koop, T.: Review of the vapour pressures of ice 
and supercooled water for atmospheric applications, Q. J. Roy. Meteorol. Soc., 131, 1539-1565, doi:10.1256/qj.04.94, 2005.

Murray, B. J.: Inhibition of ice crystallisation in highly viscous aqueous organic acid droplets, Atmos. Chem. Phys., 8, 54235433, doi:10.5194/acp-8-5423-2008, 2008.

Penner, J., Andreae, M., Annegarn, H., Barrie, L., Feichter, J., Hegg, D., Jayaraman, A., Leaitch, R., Murphy, D., Nganga, J., and Pitari, G.: Climate Change 2001: The Scientific Basis: Chapter 6 Radiative Forcing of Climate Change, 2001.

Rogers, D. C., DeMott, P. J., Kreidenweis, S. M., and Chen, Y.: Measurements of ice nucleating aerosols during SUCCESS, Geophys. Res. Lett., 25, 1383, doi:10.1029/97GL03478, 1998.

Rogers, R. and Yau, M.: A short course in cloud physics, Oxford: Butterworth Heinemann, 3rd edn., 1996.

Saathoff, H., Moehler, O., Schurath, U., Kamm, S., Dippel, B., and Mihelcic, D.: The AIDA soot aerosol characterisation campaign 1999, J. Aerosol Sci., 34, 1277, http://openurl.man.ac.uk/sfxlcl3?sid=ISI:WoS;issn=0021-8502; date $=2003$; spage $=1277$; volume $=34$; issue $=10,2003$.

Sassen, K. and Dodd, G. C.: Homogeneous Nucleation Rate for Highly Supercooled Cirrus Cloud Droplets, J. Atmos. Sci., 45, 1357-1369, 1988.

Schnaiter, M., Gimmler, M., Llamas, I., Linke, C., Jäger, C., and Mutschke, H.: Strong spectral dependence of light absorption by organic carbon particles formed by propane combustion, Atmos. Chem. Phys., 6, 2981-2990, doi:10.5194/acp-6-2981-2006, 2006.

Schwarz, J. P., Gao, R. S., Fahey, D. W., Thomson, D. S., Watts, L. A., Wilson, J. C., Reeves, J. M., Darbeheshti, M., Baumgardner, D. G., Kok, G. L., Chung, S. H., Schulz, M., Hendricks, J., Lauer, A., Karcher, B., Slowik, J. G., Rosenlof, K. H., Thompson, T. L., Langford, A. O., Loewenstein, M., and Aikin, K. C.: Single-particle measurements of midlatitude black carbon and light-scattering aerosols from the boundary layer to the lower stratosphere, J. Geophys. Res.-Atmos., 111, D16207, doi:10.1029/2006JD007076, 2006.
Schwarz, J. P., Spackman, J. R., Fahey, D. W., Gao, R. S., Lohmann, U., Stier, P., Watts, L. A., Thomson, D. S., Lack, D. A., Pfister, L., Mahoney, M. J., Baumgardner, D., Wilson, J. C., and Reeves, J. M.: Coatings and their enhancement of black carbon light absorption in the tropical atmosphere, J. Geophys. Res., 113, D03203, doi:10.1029/2007JD009042, 2008.

Schwarzenbock, A., Mertes, S., Heintzenberg, J., Wobrock, W., and Laj, P.: Impact of the Bergeron-Findeisen process on the release of aerosol particles during the evolution of cloud ice, Atmos. Res., 58, 295-313, 2001.

Seifert, M., Ström, J., Krejci, R., Minikin, A., Petzold, A., Gayet, J.F., Schumann, U., and Ovarlez, J.: In-situ observations of aerosol particles remaining from evaporated cirrus crystals: Comparing clean and polluted air masses, Atmos. Chem. Phys., 3, 10371049, doi:10.5194/acp-3-1037-2003, 2003.

Slowik, J. G., Cross, E. S., Han, J.-H., Davidovits, P., Onasch, T. B., Jayne, J. T., Williams, L. R., Canagaratna, M. R., Worsnop, D. R., Chakrabarty, R. K., Moosmuller, H., Arnott, W. P., Schwarz, J. P., Gao, R.-S., Fahey, D. W., Kok, G. L., and Petzold, A.: An Inter-Comparison of Instruments Measuring Black Carbon Content of Soot Particles, Aerosol Sci. Tech., 41, 295314, 2007.

Stephens, M., Turner, N., and Sandberg, J.: Particle identification by laser-induced incandescence in a solid-state laser cavity, Appl. Optics, 42, 3726-3736, 2003.

Tabazadeh, A., Toon, O. B., Clegg, S. L., and Hamill, P.: A New Parameterization of H2SO4/H2O Aerosol Composition: Atmospheric Implications, Geophys. Res. Lett., 24, 1931-1934, doi:10.1029/97GL01879, 1997.

Wagner, R., Linke, C., Naumann, K.-H., Schnaiter, M., Vragel, M., Gangl, M., and Horvath, H.: A review of optical measurements at the aerosol and cloud chamber AIDA, J. Quant. Spectrosc. Ra., 110, 930-949, 2009.

Zobrist, B., Marcolli, C., Pedernera, D. A., and Koop, T.: Do atmospheric aerosols form glasses?, Atmos. Chem. Phys., 8, 52215244, doi:10.5194/acp-8-5221-2008, 2008. 